\title{
The americanism of Aureliano Cândido Tavares Bastos
}

\section{Bruno Gonçalves Rosi ${ }^{1 ; 2}$}

Aureliano Cândido Tavares Bastos was one of the main ideologists of the Brazilian Liberal Party in the 1860s and 1870s. Through several books, pamphlets and articles, Tavares Bastos defended that Brazil should follow a greater political and administrative decentralization, granting greater autonomy to the provinces. Another way to summarize Tavares Bastos's political thinking is to say that he had great admiration for the United States, and understood that Brazil should, within the possibilities, copy more the political model of this country. Thus, this text interprets the political thinking of Tavares Bastos emphasizing as central factor of this the proposal that Brazil should not only more closely copy US federalism, but also get closer to the US in its foreign policy.

Tavares Bastos - Americanism - political thought international relations - liberalism.

Westminster Theological Seminary - Glenside - Pensilvania - Estados Unidos da América

2 Mestre em Relações Internacionais pela Pontifícia Universidade Católica do Rio de Janeiro. Doutor em Ciência Política pelo Instituto de Estudos Sociais e Políticos da Universidade Estadual do Rio de Janeiro. E-mail: brosi@student.wts.edu. 


\section{$\mathrm{O}$ americanismo de Aureliano Cândido Tavares Bastos}

Aureliano Cândido Tavares Bastos foi um dos principais ideólogos do Partido Liberal brasileiro nas décadas de 1860 e 1870. Através de diversos livros, panfletos e artigos, Tavares Bastos defendeu que o Brasil deveria seguir uma maior descentralização política e administrativa, conferindo maior autonomia às províncias. Outra forma de resumir o pensamento político de Tavares Bastos é afirmar que ele possuía enorme admiração pelos Estados Unidos e entendia que o Brasil deveria, dentro das possibilidades, copiar mais o modelo político daquele país. Dessa forma, este texto interpreta o pensamento político de Tavares Bastos destacando como seu fator central a proposta de que o Brasil deveria não apenas acompanhar mais de perto o federalismo norte-americano, mas também aproximar-se mais dos EUA em sua política externa.

Tavares Bastos - americanismo - pensamento político relações internacionais - liberalismo. 
The main objective of this text is to examine the political ideas of Aureliano Cândido Tavares Bastos, highlighting mostly the central role that the United States occupied in these. Lawyer, politician, writer and journalist, Tavares Bastos was the greatest admirer of the United States among nineteenth-century Brazilian politicians. During his brief but prolific parliamentary career, he argued more than anyone in his time that Brazil should direct its foreign policy toward the North-American country, while at the same time taking the United States as an example for policies taken at home.

The United States declared its independence from England in 1776. Almost fifty years later, in 1822, Brazil declared its independence from Portugal. It is natural that at some point after its independence Brazil would consider the United States as an example for itself. Perhaps not an example to be followed, but an example to be avoided, but still: independence in the American continent in the late 18th and early 19th century is part of a common historical moment, and it would be natural that the older country would become a topic of discussion for the younger ones, including Brazil.

After some twenty years of Conservative rule in Brazil, Tavares Bastos was the main voice to defend a classic liberal model for Brazilian politics. Among his most important political projects was the defense of greater decentralization of the country, with greater autonomy granted to the provinces ${ }^{3}$, as well as the defense of classical

3 There is a great bibliography on the debates over centralization and decentralization in Brazil in the $19^{\text {th }}$ century. Unfortunately, for lack of space and not to lose my focus in Tavares Bastos, I cannot make a full exposition of this bibliography. However, for one interested in the debate over centralization and decentralization I would recommend reading, among others, the following: BRANDÃO, Gildo Marçal. Linhagens do pensamento político brasileiro. São Paulo: Aderaldo \& Rothschild Editores, 2007; CARVALHO, José Murilo de. A construção da ordem. Brasília: Editora da UnB, 1980; Idem. Federalismo y centralización en el Imperio brasileño: historia y argumento. In: CARMAGNANI, Marcelo (org.). Federalismos latinoamericanos: Mexico/ Brasil/ Argentina. México: Fondo de Cultura Económica, 1993; Idem. CARVALHO, José Murilo de (org.). Entre a autoridade e a liberdade [Introdução]. Paulino José Soares do Souza, visconde do Uruguai. São Paulo: Editora 34, 2002; COSER, Ivo. O debate entre centralizadores e federalistas no século XIX: a trama dos conceitos. Rev. Bras. Ci. Soc., São Paulo, vol. 26, n. 76, p. 191-206, junho 2011; 
liberal principles such as religious freedom, freedom of trade and economic freedom in general, including the abolition of slavery. But in all this was the belief that the United States was a model that Brazil should follow more closely. According to Tavares Bastos, although perfect match between the two countries was impossible because of their different colonial backgrounds, much of what was practiced politically in the United States could and should be transposed into Brazil.

Tavares Bastos is important, among other things, for understanding the United States as a possible model for Brazil in a time when most other Brazilian political thinkers thought otherwise. Although it is rare to see true anti-Americanism (in the sense of considering the United States an enemy), most political thinkers of the day believed that Brazil and the United Sates were just so different in some fundamental ways that the United States were simply not a fit model for Brazil. The monarchies in Europe would fit this role better.

Underlying the debate about the US as a model was a notion that presumed Brazil or Latin America somehow unsuited to US style government. Going beyond the popular stereotypes, many Brazilian political thinkers did believe that the "Latin temperament" was too volatile, as compared to the Teutonic or Anglo Saxon traits, for democratic

FERREIRA, Gabriela Nunes. Centralização e descentralização no Império: o debate entre Tavares Bastos e o visconde do Uruguai. São Paulo: Departamento de Ciência Política da Universidade de São Paulo/ Editora 34, 1999; MATTOS, Ilmar Rohloff de. O Tempo Saquarema, 5 a ed. São Paulo: Editora Hucitec, 2004; REGO, Walquiria. Um liberalismo tardio: Tavares Bastos, reforma e federação. 1989. Tese (Doutorado em Ciência Política), Departamento de Ciência Política, Universidade de São Paulo, São Paulo, 1989. The topic of Americanism is closely related to the topic of centralization and decentralization, and some of the most important publications on this topic are the following: SANTOS, Wanderley Guilherme dos. Ordem burguesa e liberalismo político. São Paulo: Duas Cidades, 1978; VIANNA, Luis Werneck. A revolução passiza: iberismo e americanismo no Brasil. Rio de Janeiro: Revan, 1997; Idem. Americanistas e iberistas: a polêmica de Oliveira Viana com Tavares Bastos. Dados Revista de Ciências Sociais, Rio de Janeiro, vol. 34, n. 3, 1991, p. 145-189. 
forms of government. Although Tavares Bastos didn't escape completely this kind of thinking, he did it to a great degree transcending $\mathrm{it}^{4}$.

Concerning the organization of this text, I try to follow as closely as possible the chronological order of Tavares Bastos' life, highlighting some episodes generally considered central to his political career and especially to his writings ${ }^{5}$. Regarding these writings, I try to make a brief general presentation, but I highlight the references to the USA as an example for Brazil and as an international partner to be privileged in Brazilian foreign policy. These considerations explain the sections of this paper.

\section{Early years and early political career}

Aureliano Cândido Tavares Bastos was born in the city of Alagoas, today Marechal Deodoro, Alagoas, on April 20, 1839. Son of José Tavares Bastos and Rosa Cândida de Araújo, he belonged to a family of prestige in the region: his father was a latinist and professor of philosophy, and was a judge, provincial deputy and minister of the Supreme Court of Justice, as well as political opponent of the local liberal leader, Cansanção de Sinimbu.

After studying with his father and preparing in Olinda, Tavares Bastos joined the Law School of the same city in 1854 (the year the college moved to Recife). Since he was only 15 years old, he needed a special license to enter. The following year, he accompanied his father, who was appointed president of the province of São Paulo, transferring to the Faculty of Law, where he graduated in 1858, and received a Doctor of Law degree in 1859, defending liberal ideas: his thesis was about the burden of taxes on foodstuffs consumed in the country.

4 It is not my intention here to make a deeper analysis of the Brazilian political leaders who thought this way, but one interested in this theme can look for publications on the main leaders of the Conservative Party, such as Bernardo Pereira de Vasconcelos, viscount of Uruguai and José Maria Paranhos.

5 Although some might find this approach repetitive, I still believe this is the best way to appreciate Tavares Bastos' thought. For one thing, it helps us see how some ideas followed him through a long time throughout his career. 
In the college he established important political relations that would accompany him during his career: Lafayette Rodrigues Pereira, Silveira Martins, Paulino de Sousa, Ferreira Viana, Afonso Celso (father), Tomás Coelho, Macedo Soares and Pedro Luís, among others. Still in the period of college in Olinda he was dedicated to the literary studies and, after transferring to São Paulo, taught French and philosophy in a private school. He even prepared a literature course for his siblings, which was even partially published in 1860 in the academic journal Kaleidoscópio. He also participated actively in academic societies (notably the Instituto Acadêmico Paulistano), as well as contributing to literary and philosophical journals. But these literary inclinations would end when, in the footsteps of his father, he entered the political career.

Soon after graduating, Tavares Bastos moved to Rio de Janeiro, where he was appointed Navy secretary in 1860. In the same year, he applied to the Legislative General Assembly, and ironically supported by Cansanção de Sinimbu, formerly political adversary of his father, got to elect by the Liberal Party. On this occasion he was, at the age of 22, the youngest member of Parliament. He would be reelected for 1864-1866 and 1867-1870, always by the Liberal Party.

According to Evaristo de Morais Filho, Friedrich Hegel was the most basic intellectual influence on the thought of Tavares Bastos. Still according to Evaristo, in economics Tavares Bastos had a predilection for Bastiat, Molinari, Guillaumin, Chevalier, Cobden, Bright and the Gournal des Economists. In public law he was based in Barrot, Vivien, Montalembert, Béchard, Laboulaye, Prevost Paradol, Guizot and Benjamin Constant. May, Paschal, Tocqueville, Kent and the Federalist Papers were his references in American law. Tavares Bastos had also deep knowledge of English constitutional history and liberal thought, especially of John Stuart Mill and Jeremy Bentham. But this vast knowledge never made Tavares Bastos an intellectual confined to his office: "direct knowledge of things and facts" played an even more

${ }_{6}$ MORAIS FILHO, Evaristo de. As ideias fundamentais de Tavares Bastos. Rio de Janeiro: Difel, 1978. p. 3. 
relevant role in his ideas. In this sense, although respected the limitations of the time, Tavares Bastos made some trips to observe in loco the world about which he legislated.

Tavares Bastos' political career was marked by concern with the social and economic issues of his time, especially slavery, immigration, free navigation of the Amazon, education and religious freedom. During his lifetime, Parliament discussions on religious freedom and the separation of church and state, immigration and electoral and parliamentary reform prevailed $^{7}$. Although he never rose to a position higher than that of deputy, Tavares Bastos stood out in Brazilian politics by producing a reasonable amount of texts, between books and pamphlets. More than a complement to his parliamentary activities, writings were an integral part of his political career ${ }^{8}$.

\section{The "Eccentric"}

The first text of Tavares Bastos to call attention of the Brazilian political milieu was a pamphlet called "Os males do presente e as esperanças do futuro", published on July 29, 1861 under the pseudonym $A n$ Eccentric. The pamphlet had only 35 pages, divided into three parts reality; illusion; solution -, but had a deep impact in Brazilian politics ${ }^{9}$.

The "Eccentric" found in the Portuguese heritage all the ills of Brazil. The Portuguese despotism of the 16th century had, according to him, been marked by a "rapacious and indolent nobility" 10 . And this Portuguese despotism, continued the author, ended up contaminating the individuals who migrated to Brazil ${ }^{11}$. Completing the unfavorable

7 VAINFAS, Ronaldo (org.). Dicionário do Brasil imperial. Rio de Janeiro: Objetiva, 2008. p. 689-690.

8 TAVARES BASTOS, Aureliano Cândido. Os males do presente e as esperanças do futuro, $2^{\mathrm{a}}$ ed. São Paulo: Companhia Editora Nacional, 1976 [1861]. p. 14-15.

9 Ibidem.

10 Ibidem, p. 28.

11 Ibidem, p. 30. 
picture for the future of Brazil were two more elements: slavery ${ }^{12}$ and closed ports ${ }^{13}$.

Even after independence the evils of the colonial system persisted. The independence leaders, "educated in the darkness of Coimbra", possessed "vicious classical education and youthful admiration of the ancient heroes" and "heads full of memories of Cesar and Pompey", all with "anachronistic and deleterious consequences". Yet they were "men superior to their time and their country", led by a "generous prince", and succeeded in bequeathing the "sensible, national and glorious constitution of 1824". In spite of this, "their strength was small for the mammoth task of making every Brazilian a truly free, independent and sovereign man" 14 .

Tavares Bastos walks through the history of Brazil and arrives in 1831. There, "all the germs of the greatest practical, administrative and political freedom, entrusted to the bosom of the country still throbbing with enthusiasm, became elements of partial revolts and general disorder". The reformers tried to copy the US, but "they did not see the deep differences that distinguished and distinguish the two countries". "They did not attend to the physiognomy of this special society, in which the highest spirit of freedom is perfectly aligned with respect for customs, traditions and even aristocratic institutions, such as hereditary substitutions, according to Tocqueville's testimony".

The result was "the ineffectiveness of the great movement of 1831, its degeneration, and consequently the reaction begun eight years later and still dominant today". But there are evils that come to good, for

Proclaimed, the republic would find no able chief, nor dignified servants of government. Demagogy could only invoke, instead of Washington or Lafayette, the frenzy of the demolishers, the Carbonarians, Manin, Mazzini ... God! Was the rough lesson of 48 and 49 so soon forgotten? The second day of the republic was to be the first of anarchy and the eve of the exaltation of a despot.

12 Ibidem.

13 Ibidem p. 31.

14 Ibidem, p. 31-32. 
The caudillos would succeed the caudillos, as in Mexico (...), as in the Rio de la Plata ${ }^{15}$.

Brazil did not have the elements for regime change and was also trapped in an almost despotic regime. "Revolution leads to anarchy, anarchy to despotism, and despotism to revolution ... Eternal vicious circle" 16 . What would be the solution? This is the theme of the last part of the pamphlet. According to Tavares Bastos, "a strong but democrat government, like that of England", "on the eternal bases of authority without tyranny, of freedom without demagogy". Not that such a government can "do everything, heal all the vices, in one day, in an hour, by magic". "But its energy and morality, activity, and intelligence may lay certain foundations upon which the social edifice rests and strengthens itself" ${ }^{\prime 17}$. And there are some more specific reforms that the author wishes to pursue: direct election, administrative decentralization, public education reform, independence of the judicial power, national defense reform, tax reform, economic reform, free cabotage law, opening the Amazon to world trade, to the over-abundant emigration of the United States, of the Irish, of the Germans, of the Swiss etc., slow emancipation of slavery, reconstituting on natural bases the organization of labor and, finally, as a result of all this, improvement of the country's image abroad ${ }^{18}$.

The United States is a constant reference in Os males do presente e as esperanças do futuro. From the outset, Tavares Bastos makes it explicit to take the US as a model for Brazil: "The example of the United States clearly characterizes our thinking. Yes, we did not know the public spirit, nor the freedom of the individual, at the beginning of this century" ${ }^{\prime 19}$. However, Tavares Bastos understands that there are differences between Brazil and the United States that must be considered when

15 Ibidem, p. 45-46.

16 Ibidem, p. 47.

17 Ibidem, p. 48-49.

18 Ibidem, p. 50-51.

19 Ibidem, p. 31. 
transposing the model into a new context ${ }^{20}$. One of the policies advocated by Tavares Bastos in this book is to encourage the immigration of Americans to Brazil ${ }^{21}$. However, taking advantage of the immigration issue, Tavares Bastos highlights the differences between Brazil and the United States. The US had a great facility to attract immigrants, Brazil did not ${ }^{22}$. That is, for him the policy of attraction of immigrants needed to be inserted in a wider context of transformations Brazil had to go through.

One of the characteristics of Tavares Bastos' political thinking is precisely that different themes are not treated separately, as isolated ones. In general they are interconnected in a broader program, of which they are constituent parts. As an example of this, it may be mentioned that immigration was linked to the end of slavery in his writings ${ }^{23}$. Another issue related to immigration (and abolition) in the writings of Tavares Bastos was the establishment of better maritime connections between Brazil and the United States ${ }^{24}$. The land legislation is another theme mentioned by Tavares Bastos within the causal link previously initiated. And again the US appears as a reference to the author ${ }^{25}$. The connection between the various themes is clear enough for Tavares Bastos: immigration, especially of Americans, is essential for Brazil's progress. But this immigration depends on the end of slavery (and vice versa) and Brazil's better maritime connections with the world. In all this, the United States is an example for Brazil.

\footnotetext{
20 Ibidem, p. 45-46.

${ }^{21}$ Ibidem, p. 50-51.

22 Ibidem p. 59.

23 Ibidem, p. 68-69.

24 Ibidem, p. 70-71.

25 Ibidem, p. 80-83.
} 
However, it is important to mention once again that Tavares Bastos sees important differences between Brazil and its model ${ }^{26}$.

\section{3. "The Solitary"}

In 1861 Tavares Bastos was exonerated from the position of secretary of the Navy, in reprisal against a speech he delivered at the Congress in disagreement with the minister. In response to his resignation Tavares Bastos published a series of 30 articles in the newspaper Correio Mercantil between September 1861 and April 1862, the so-called Cartas do Solitário. The letters were collected in a book and published as early as May $1862^{27}$.

Although still in 1862 Jose Maria da Silva Paranhos gave a speech justifying the dismissal of Tavares Bastos, the damage was already done. Cartas do Solitário drew even the attention of dom Pedro II, who agreed to some extent with the ideas of Tavares Bastos, although he could not imagine that the author behind the pseudonym was a young deputy. He believed, like Paranhos, that the Solitary's articles were being paid by "US interests". Later, upon discovering who the Solitary was, dom Pedro II made disparaging remarks about Tavares Bastos, even considering him too young to be taken seriously ${ }^{28}$.

If the emperor agreed very much with the Solitary (without knowing yet the author of the texts), the same cannot be said of José Maria da Silva Paranhos, the viscount of Rio Branco. As Finance minister (1861 to 1862) of the Caxias cabinet (March 1861 to May 1862), he received many critics from Tavares Bastos in the pages of Cartas do Solitário ${ }^{29}$. For example, in Appendix I of the book, dealing with manufacturing industry and protective tariffs (expanding Letter III, of Oc-

\footnotetext{
26 Ibidem, p. 75.

27 TAVARES BASTOS, Aureliano Cândido. Cartas do Solitário, 4a ${ }^{\mathrm{a}}$ ed. São Paulo: Companhia Editora Nacional, 1975 [1862], p. 19 e 30.

28 Diário de 1862. Introdução e notas de Hélio Viana. Separata do Anuário do Museu Imperial, Petrópolis, vol. 17, p. 64, 75, 149, 1956.

29 TAVARES BASTOS, Aureliano Cândido. Op. Cit., 1862. p. 360, 439, 501, 504.
} 
tober 12), Tavares Bastos complained about the protectionist policy practiced by Paranhos ${ }^{30}$ : while Paranhos (and Conservatives in general) considered their measures already too liberal (preoccupied with the loss of revenue and the loss of specific interests), Tavares Bastos saw protectionism still excessive in Brazil's customs laws ${ }^{31}$.

But the main point of contention between Tavares Bastos and Paranhos was the opening of the Amazon to international shipping and trade. Writing about the free navigation of the great rivers in Letter XXV (of December 27), Tavares Bastos complained that Paranhos opposed the opening of Brazilian rivers (centrally the Amazon) to international navigation using outdated concepts of international law that did not reflect natural rights ${ }^{32}$. In Appendix VI of the book (referring to letters XXI to XXX) Tavares Bastos also criticized Paranhos for defending the monopoly of Brazilians in steam navigation projects for the United States ${ }^{33}$.

The criticism made by Tavares Bastos to Paranhos in Cartas do Solitário continued in a subsequent book, $O$ vale do Amazonas: estudo sobre a livre navegação do Amazonas, estatística, produções, questões fiscais do vale do Amazonas, com um prefácio contendo o decreto que abre aos navios de todas as nações os rios Amazonas, Tocantins e S. Francisco, of 1866. Tavares Bastos defended the opening of the Amazon to international navigation, arguing that the principle of free navigation was traditionally defended by Brazil since independence. He believed that, contrasting this, Paranhos was responsible for presenting sophistical arguments in an opposite direction, saying that this principle had already been repudiated by the Brazilian government ${ }^{34}$.

30 Ibidem, p. 438-439.

31 Ibidem, p. 440-441.

32 Ibidem, p. 360-361.

33 Ibidem, p. 504.

34 TAVARES BASTOS, Aureliano Cândido. O vale do Amazonas. São Paulo: Companhia Editora Nacional, 1937 [1866], p. 42. 
In dealing with "conditions indicated as preliminary to the free trade of the Amazon", Tavares Bastos once again criticized Paranhos. According to him, Rio Branco paid lip service the opening of the Amazon, but justified the delay in doing so by presenting the need for new regulations, legislative approvals and new bureaucratic measures ${ }^{35}$. Tavares Bastos considered that many of Paranhos' considerations were only "useless delays": his reflections were occasionally "sensible" but often dispensable. With this, Tavares Bastos complained about those "whose political mission in this country has been to entangle the issues by the laziness of solving them with decision" ${ }^{36}$. In contrast to this, Tavares Bastos invited readers to open the Amazon in a resolute way, without petting ${ }^{37}$.

Tavares Bastos also attacked Paranhos in speeches in the Congress and in his mission to the La Plata region ${ }^{38}$. On July 11, 1862, he questioned Paranhos in the Chamber of Deputies regarding the opening of the Amazon. He accused the Conservative government of following a selfish and "unfit for the present century" policy by wanting the exclusive navigation for the river. Paranhos defended the government, affirming in the first place that the accusation did not proceed: the imperial government did not want the exclusivity of navigation. It only followed "what is written in the best treaties of the rights of the people"39.

Paranhos openly stated that the purpose of his policy for the Amazon was "to prevent our territory in the Amazon from being violated by the expeditions of filibusters who were preparing for that in the United States" ${ }^{\prime 4}$. Despite his concern for American filibusters, Paranhos made a caveat that his concern was not with the US government itself, but with individuals who harbored in US territory. Still, he criticized the

35 Ibidem, p. 59-61.

36 Ibidem, p. 69.

37 Ibidem, p. 70.

38 MORAIS FILHO, Evaristo de. As ideias fundamentais de Tavares Bastos. Rio de Janeiro: Difel, 1978. p. 20.

39 PARANHOS, José Maria da Silva [Alvaro da Costa Franco, org.]. Com a palavra, o visconde do Rio Branco: a política exterior no Parlamento imperial. Rio de Janeiro: CHDD; Brasília: Funag, 2005. p. 208.

40 Ibidem, p. 247. 
United States for trying to persuade the Brazilian government to adopt too broad principles, although in the end they recognized that "from the territory of the American Union, filibusters would come to the Amazon". With sarcasm, Tavares Bastos replied: "Very well; I thought it was anarchy to praise the United States, now I see that it is not" ${ }^{\prime \prime 1}$.

Cartas do Solitário is divided into three series. The first deals with Administrative Organization and Religious Education. The second series deals with the issue of Free Africans and Trafficking of Blacks. The third series is about The Laws of Navigation. The Coastal Trade. The Openning of the Great Rivers. Issue of Amazonas Direct: Communications between the two Americas. But ultimately the letters are more comprehensive than these titles may suggest. They continue and broaden the discussion of the matters already mentioned in Os males do presente e as esperanças do futuro. Again there are themes such as decentralization and federalism, freedom and many references to the United States, as well as the opening of the Amazon to international shipping and trade, Protestant immigration and the creation of a line of steam ships connecting Rio de Janeiro and New York ${ }^{42}$. The solution to all the problems in Brazil (from their Portuguese roots) remained the same: freedom of $\operatorname{trade}^{43}$, recognition of an international division of labor and the comparative advantage of focusing on agriculture ${ }^{44}$, opening not only the Amazon, but all the rivers to international trade ${ }^{45}$ and, finally, immigration (especially from the US) ${ }^{46}$. In short, a classic liberal recipe, or something close to it.

If in Os males do presente the references to the United States were already numerous, in Cartas do Solitário they are even more abundant. In the first series of letters, addressing the "Administrative Organization"

\footnotetext{
41 Ibidem, p. 247-248.

42 TAVARES BASTOS, Aureliano Cândido. Op. Cit., 1862. p. 77, 83, 171, 176.

43 Ibidem, p. 357-358.

44 Ibidem, p. 267-274.

45 Ibidem, p. 325-398.

46 Ibidem, p. 414-416.
} 
of Brazil, this can already be observed. In letters III and IV Tavares Bastos writes about "Centralization. Its vices in the center and its results in the provinces". Instead of only lamenting the bad sociological conditions of Brazil (as the Conservatives did), Tavares Bastos proposed to seek in other examples a better way out for Brazil: a federative, albeit a monarchist, government ${ }^{47}$.

In the second series of letters, dealing with "Free Africans and Traffic of Negros", Tavares Bastos aims to prove that "Brazil could dispense the slave trade", replacing slave labor by American and European immigrants, and that even if it were not possible to attract immigrants, it would be useful to end slavery in any case because of its ills for Brazil ${ }^{48}$. Again the United States are an example. Tavares Bastos does not deny that slavery continued to be practiced in parts of the United States, especially in the south of the country, in a practice he calls "savage" 49 , but he also states that the United States was the first country to condemn the slave trade (and not France or England, which just followed its example $)^{50}$.

The largest number of letters (18 out of a total of 30) is in the third series, "The Navigation Laws. The Coastal Trade. The Openning of the Great Rivers. Issue of Amazonas Direct: Communications between the two Americas". In this series, Tavares Bastos defends the opening of the Amazon river to international navigation, direct steam navigation to the United States and the opening of the Brazilian navigation market to foreign companies. This is the series of letters most directly linked to issues of international politics. Although Tavares Bastos never held the post of Foreign minister, it may be noted that his ideas on the subject followed a well-founded line. Essentially he defended the benefits of free trade, or the end of Brazilian isolation in a broader way. Brazil should open itself not only to trade flows, but to open

\footnotetext{
7 Ibidem, p. 65-66

48 Ibidem, p. 163

49 Ibidem, p. 180.

${ }^{50}$ Ibidem, p. 148-149.
} 
up more broadly to immigration and navigation. The result would be greater contact with the world, especially with the United States.

At the conclusion of his penultimate letter Tavares Bastos asks "What is this Republican country, however, that so much terror inspires the imaginations of our statesmen?" 51 . I believe there would be no better way to sum up his thinking about the United States than this.

\section{The Amazon Valley}

In 1864 Tavares Bastos participated as secretary in the Saraiva Mission to the Río de la Plata basin, which gave cause to great controversy in the House. The following year he traveled to the Amazon as part of his campaign for freedom of navigation. In 1866 he published $O$ vale do Amazonas: estudo sobre a livre navegação do Amazonas, estatística, produções, questões fiscais do vale do Amazonas, com um prefácio contendo o decreto que abre aos navios de todas as nações os rios Amazonas, Tocantins e S. Francisco. A book with a rather long title, but with a precise objective: to reinforce the opinions already shown in his previous writings that the Amazon river and its tributaries should be open to international navigation.

The theme of the opening of the Amazon to international shipping and commerce had already appeared in Males do presente and Cartas do Solitário. In Cartas do Solitário Tavares Bastos noted that the main objection to the opening of the Amazon was that this would benefit only the United States. Some Brazilian public opinion also stated that the Americans were filibusters and that they would seize the Brazilian territory (or part of it) if they could. Others said that the Americans were anarchists and that they wanted to overthrow the monarchy. Tavares Bastos repudiated these arguments as prejudice and propaganda created by hidden individual interests that feared competition with the foreigner ${ }^{52}$. Also in Cartas do Solitário the theme of the opening of the Amazon was linked to the greater theme of freedom of commerce.

Ibidem, p. 411.

52 Ibidem, p. 333-345. 
Tavares Bastos understood that Brazil should not fear the competition present in the free market. In his view, the obstruction to navigation of the Brazilian rivers and seas was a barrier to progress, and the selfish demands of the monopolies were a poison that destroyed the country. All this came from the Brazilian character, marked by selfishness: Brazilians preferred to "sit upon" their unexplored resources to share them with the world ${ }^{53}$.

$O$ vale do Amazonas expanded the examination initiated in Cartas do Solitário. Once again Tavares Bastos defends the approach with the United States. He also denies that the United States was acting imperialistically against Brazil. On the contrary: according to him, in the case of the opening of the Amazon the United States proceed "deserves praise". Tavares Bastos explains that other countries bathed by the Amazon basin adopted the policy of free navigation, which was interesting not only to the US government, but also to private companies that wanted to explore the navigation of the rivers of the region. Although Brazil was the only country in the region to adopt a different policy, the United States had no choice but to give in to Brazilian policy, respecting what was defined as a right of Brazil. Tavares Bastos considers that the Brazilian refusal weighed negatively against the US, but much more against Brazil. While US policy was popular across the continent, Brazil's policy gained only antipathy, according to the deputy $^{54}$. The US, in turn, did not question Brazilian isolationism ${ }^{55}$.

Tavares Bastos defended not only the opening of the Amazon and free trade with the US through it, but also the incorporation of US companies with its technology in the navigation of this. He was also opposed to the navigation monopoly in the region handed over to Irineu Evangelista de Sousa, viscount of Mauá ${ }^{56}$. The situation of

\footnotetext{
53 Ibidem, p. 236-266 e 358-359.

54 TAVARES BASTOS, Aureliano Cândido. O vale do Amazonas. São Paulo: Companhia Editora Nacional, 1937 [1866]. p. 37.

55 Ibidem, p. 18.

56 Ibidem, p. 347.
} 
the Indians in the Amazon was also a matter of concern in the opening of the rivers to navigation. Regarding this matter Tavares Bastos answered that it was not the responsibility of the government, directly or indirectly to do catechesis of the Indians; and that it was also not the responsibility (or competence) of the Catholic Church to "teach agriculture and rehearse an Indian in the industries". Tavares Bastos believed that the action of time and contact with the civilized people would slowly transform if not the present-time Indians, at least their descendants to live with the whites. Once again the United States is an example for Brazil: the Indians are expected to be civilized by contact with whites ${ }^{57}$.

It was clear for Tavares Bastos that one of the most central objections to opening the Amazon was the hypothetical presence of American filibusters who would take advantage of the circumstances to take the region for themselves. In fact, this was a Brazilian concern in the $1850 \mathrm{~s}^{58}$. Tavares Bastos, however, sought to distinguish between the misbehavior of individual Americans and US foreign policy as a whole, especially after the rise of the Republican Party to power ${ }^{59}$.

\section{Immigration}

In 1866, Tavares Bastos participated in the founding of the Sociedade Internacional de Imigração, in addition to seeing his campaigns for the freedom of navigation of cabotage and the opening of the Amazon to international trade and navigation victorious: the opening of the Amazon to trade was legally determined on December 7, 1866, and would take place the following year. In 1867 he published two texts: "Memória sobre a imigração" and "Carta política ao conselheiro Saraiva". They are relatively short texts with more circumscribed themes.

\footnotetext{
57 Ibidem, p. 361.

58 HILL, Lawrence F. Diplomatic relations between Brazil and the United States. Durham: Duke University Press, 1932. p. 220-222.

59 TAVARES BASTOS, Aureliano Cândido. Op. Cit., 1866. p. 398-399.
} 
The subject of immigration was already present in Cartas do Solitário. There, Tavares Bastos already said that the Brazilians were provincial and guided by politicians with limited vision. In contrast, Brazil needed individuals with a broader and more cosmopolitan view of the world ${ }^{60}$. Part of this process would be through the immigration of "intelligent and educated people" capable of contributing to the development of agriculture, commerce and industry, not slaves or Chinese $^{61}$. Tavares Bastos was not just a publicist in the immigration case. He was one of the leaders of the Sociedade Internacional de Imigração ${ }^{62}$, and "Memória sobre a imigração" was written on behalf of this society ${ }^{63}$.

In Cartas do Solitário, Tavares Bastos already called slavery "enemy of the immigration", demanding its abolition. According to him, Brazilian agriculture, practiced by slaves, followed the methods of African agriculture. European immigrants would teach Brazilians modern agricultural methods, thus increasing productivity ${ }^{64}$. To illustrate with an example, he compared the agriculture in Bahia (made by slaves) with that of Rio Grande do Sul (made by free workers): productivity in Rio Grande do Sul was three times higher, according to his figures. The correct type of European immigration was the solution to Brazil's agricultural and economic problems in general, as well as its backwardness ${ }^{65}$. Also in Cartas do Solitário he stated that the shortest way to bring immigrants from Europe to Brazil was through the United States ${ }^{66}$.

In "Memória sobre a imigração", Tavares Bastos defended the reform of existing legislation, liberalizing the situation of the immigrant. A practical measure would be the granting of land to immigrants, an

\footnotetext{
60 TAVARES BASTOS, Aureliano Cândido. Op. Cit., 1862. p. 183-184.

${ }^{61}$ Ibidem, p. 164-165 e 276.

62 VIEIRA, David Gueiros. O protestantismo, a maçonaria e a questão religiosa no Brasil. Brasília: Editora Universidade de Brasília, 1980. p. 223, 236, 248, 250.

63 Ibidem, p. 242.

64 TAVARES BASTOS, Aureliano Cândido. Op. Cit., 1862. p. 242.

65 Ibidem, p. 164-166.

${ }^{66}$ Ibidem, p. 415.
} 
article absent from the Immigration Act of 1860 ". Also in "Memória sobre a imigração", immigration policy crossed with another concern of Tavares Bastos: religious freedom. European (and American) Protestant (or American) immigrants needed not only freedom of worship, but also civil registry of marriage and children, as well as cemeteries ${ }^{68}$. Going beyond propaganda, on July 10, 1867 he submitted a bill in the House proposing civil marriage. The project was basically the same already submitted by Nabuco de Araújo, and rejected by the marquis of Olinda, and once again was shelved, this time by the Zacarias cabinet ${ }^{69}$.

The cry for immigration was timely. After the American Civil War (1861-1865), some of the confederate veterans (unsatisfied with the defeat) seemed willing move to Brazil. This excited Brazilian elites, who were in search of workforce to replace the Africans, since slavery was in process of abolition, especially since the end of the slave traffic in $1850^{70}$. The more excited Brazilians and Americans expected that hundreds of thousands of veterans with their families would move to Brazil. Tavares Bastos believed that the Americans would bring progress with them. With other liberals, he welcomed the confederates enthusiastically ${ }^{71}$. Some in the Brazilian government had the expectation that the former combatants could join the Brazilian forces in the Paraguayan War, bringing their military experience with them, but this expectation was completely frustrated: war weary, the veterans of the Civil War would have no business in a new conflict in South America ${ }^{72}$. It is important to notice that, diplomatically speaking, Brazil and the United States were mostly indifferent to each other before the 1860s. In this way, the Civil War didn't have a great impact in Brazil-United

\footnotetext{
TAVARES BASTOS, Aureliano Cândido. Op. Cit., 1861. p. 593.

6 Ibidem, p. 59-124.

69 Anais da Câmara, 10 de julho de 1867.

70 BURNS, E. Bradford. A aliança não escrita: O barão do Rio Branco e as relações Brasil-EUA. Brasília: Funag, 2003. p. 59.

71 VIEIRA, David Gueiros. Op. Cit., p. 216-217.

72 HILL, Lawrence F. Op. Cit., p. 241-243, 257-258.
} 
States relations ${ }^{73}$. Nevertheless, Tavares Bastos saw the rising of the Republican Party to power as sign that the relationship between the two countries would improve in the coming years ${ }^{74}$.

\section{Religious freedom}

Also in 1866 a pamphlet was published under the pseudonym of Melásporo, entitled "Exposição dos verdadeiros motivos sobre que se baseia a liberdade religiosa e a separação entre a Igreja e o Estado". It was attributed to Tavares Bastos, but this is controversial. Even more controversial is the attribution to him of "A Revolução e o Império" of the same year. Although the authorship of "Exposição dos verdadeiros motivos sobre que se baseia a liberdade religiosa e a separação entre a Igreja e o Estado" is controversial, there is no doubt that religious freedom was an important theme for Tavares Bastos. Still in September 1861, he published a letter in the newspaper Correio Mercantil, accusing the Customs of having become "the Nunciature Chancellery". He complained that an employee had seized a box of pamphlets belonging to dr. Robert Reid Kalley, a congregational missionary in Brazil ${ }^{75}$. Another example of a deputy's relationship with "non-Catholics" (as they were referred in Brazil) was the case of Alexandre Wagner, a Hungarian Protestant who financed the first edition of Cartas do Solitário. He received with enthusiasm the ideas of the Solitary, as well as (apparently) the entire Protestant community of Rio de Janeiro ${ }^{76}$. Tavares Bastos' criticisms of the Catholic Church led some to believe that the Solitary was a Protestant himself, but he refuted this view with a Catholic faith confession in Cartas do Solitário itself, though he held a critical view of Ultramontanism and "popery"

\footnotetext{
73 ROSI, Bruno Gonçalves. Brazil-USA relations from Tiradentes to baron of Rio Branco. Brazilian Journal of International Relations, Marília, vol. 6, n. 1, p. 37-60, jan/abr. 2017.

74 TAVARES BASTOS, Aureliano Cândido. Cartas do Solitário, $4^{\mathbf{a}}$ ed. São Paulo: Companhia Editora Nacional 1975 [1862]. p. 280-281, 331.

75 Correio Mercantil, Rio de Janeiro, 7 de outubro de 1861.

76 VIEIRA, David Gueiros. Op. Cit., p. 99.

77 TAVARES BASTOS, Aureliano Cândido. Op. Cit. 1862. p. 97.
} 
Dealing with religious freedom, Tavares Bastos once again contrasts Brazil's undesirable situation with the ideal situation in the United States: "For me, the ideal religious organization is that of the United States: all sects are allowed, and none is subsidized or inspected"78. He goes even further, attributing to the "liberal spirit of the Protestant Reformation" the root of American prosperity ${ }^{79}$. Tavares Bastos develops this theme in yet another passage from Cartas do Solitário, making a sociology of the effects of the "Gospel as Christ preached it" (present in the USA) in contrast to "the fanaticism of the priests" (present in Brazil $)^{80}$.

This interpretation of the relationship between Protestantism and the US, and Catholicism and Brazil, explains at least in part the defense that Tavares Bastos made of religious freedom in Brazil. Its aim was to remove the religious monopoly of the Catholic Church and to open the doors of Brazil for the migration of Protestants from Europe and the United States. In this process he approached the first Protestant missionaries to arrive in Brazil, especially since the 1850s, among them Robert Reid Kalley, founder of the Fluminense Evangelical Church, and Ashbel Green Simonton, founder of the Brazilian Presbyterian Church. Tavares Bastos also became friend of Alexander Latimer Blackford, Simonton's brother-in-law, when Blackford temporarily held the charge d'Affaires position of the American Legation for a few months in $1861^{81}$. The alagoano ended up becoming a friend and lawyer of the Presbyterians in general and especially of Blackford, writing petitions and taking care of all their legal problems $\mathrm{s}^{82}$.

Tavares Bastos' greatest ally among the protestants was James Cooley Fletcher. Fletcher was a pioneer of the missionary protestant work in Brazil and one of those who, very actively, contributed to the fight

\footnotetext{
8 Ibidem, p. 97.

79 Ibidem, p. 391-392.

80 Ibidem, p. 357-358.

81 VIEIRA, David Gueiros. Op. Cit., p. 139.

82 Ibidem, p. 240.
} 
for the complete freedom of worship in the country ${ }^{83}$. He was also the author of Brazil and the Brazilians: portrayed in historical and descriptive sketches ( $1^{\text {st }}$ edition in 1857). This book was initially a complement to Sketches of residence and travels in Brazil, embracing historical and geographical notices of the Empire and its several provinces (1845), a book written by Methodist missionary Daniel Kidder, but eventually surpassed by far the original material, becoming one of the most famous books about Brazil in the English language until early $20^{\text {th }}$ century. Fletcher was also one who fought bravely to strengthen ties between Brazil and the United States, in a time when the two countries had little mutual interest.

Starting in 1852, Fletcher made several trips to Brazil, and spent considerable time in the country, traveling all over it. Eventually he and Tavares Bastos met and became political allies ${ }^{84}$. Tavares Bastos was only thirteen years old when Fletcher first came to Brazil, and it does not seem that the both of them met personally before 1862 (Fletcher was mostly in the United Sates between 1856 and 1862), but it is not unlikely that Tavares Bastos read some articles published by Fletcher in the Brazilian press much earlier than that ${ }^{85}$.

Fletcher is mentioned by Tavares Bastos at Cartas do Solitário. On the letter number 23 (of March 21, 1862), when speaking about the opening of the Amazon river to international trade and navigation he says that at the last chapter of his work Brazil and the Brazilians, Fletcher paid justice to exaggerations made at the American press, stressing, at the same time, the great advantages of the opening of the Amazon to foreign trade ${ }^{86}$.

As I already mentioned here, the fear that filibusters could threat Brazil was strong during the 1850s in a form, if not justifiable, at least understandable. It was feared that Brazil's territorial integrity was

83 Ibidem, p. 62.

${ }^{84}$ Ibidem, p. 96-97.

85 Ibidem, p. 95-96.

86 TAVARES BASTOS, Aureliano Cândido. Cartas do Solitário, $4^{\mathbf{a}}$ ed. São Paulo: Companhia Editora Nacional 1975 [1862].p. 280-281. 
threatened, for example, by the possible independence of the province of Pará. Tavares Bastos saw this fear, especially among Conservatives $^{87}$, but believed that Fletcher and his writings were evidence that this was not justified ${ }^{88}$. In a footnote from December 1862, added to the books $2^{\text {nd }}$ edition, he made this important observation:

Behold the words of the writer friend of Brazil [emphasis added]: "Brazil certainly has the right, and the sole right, to control the rivers within her own borders, no matter if they do rise in other states... Still, although we rejoice to see Brazil developing her own resources, it would be of incalculable benefit to herself as to the neighboring states if she would apply to the Amazon question the principles for which she contended on the La Plata, and throw the mighty river open to the commerce of the world". (Brazil and Brazilians. Philadelphia, 1859. p. 530-531.) The illustrious traveler, author of this book [emphasis added], just traveled through the Amazon Valley. His impressions and writings about this part of the Empire are probably to be published in North America, and this shall not be the last important service he provided to the Brazilian people [ditto] (December, 1862) ${ }^{89}$.

Fletcher was not the only "friend of Brazil" quoted by Tavares Bastos in his Cartas do Solitário. He also referred to Thomas Rainey, Fletcher's friend and collaborator in the writing of Brazil and the Brazilians. In the Letter 29 (of March 28, 1862) Tavares Bastos talked about the direct steam navigation between Brazil and the United States (a subject connected to the opening of the Amazon river) ${ }^{90}$ using Rainey's book Ocean steam navigation and the ocean post as a source to defend the break of national monopoly over steam navigation, opening competition to foreign companies ${ }^{91}$.

87 Ibidem, p. 331.

88 GAYLE, Thornbrough; RIKER, Dorothy; CORPUZ, Paula (ed.). The diary of Calvin Fletcher, 1848-1852, including letters to and from Calvin Fletcher. Indianapolis: Indiana Historical Society, 1975. vol. IV, p. xii; Idem. The diary of Calvin Fletcher, 1853-1856, including letters to and from Calvin Fletcher. Indianapolis: Indiana Historical Society, 1977. vol. V, p. xx; Idem. The diary of Calvin Fletcher,1857-1860, including letters to and from Calvin Fletcher. Indianapolis: Indiana Historical Society, 1978. vol. VI, p. xxi.

89 TAVARES BASTOS, Aureliano Cândido. Op. Cit., 1862. p. 280-281.

90 Ibidem, p. 331.

91 Ibidem, p. 338-340. 
Tavares Bastos's defense was not limited to the Congregationalists and Presbyterians already mentioned: he also defended the Anglicans in Recife ${ }^{92}$. And this defense of evangelicals and freedom of worship became another important topic in the political career of Tavares Bastos, so much so that the Catholic newspaper $O$ Apóstolo attacked him in 1865, the same way as it did with the evangelical missionaries ${ }^{93}$. At first Tavares Bastos opposed the total separation between church and state $^{94}$, but when the Religious Question broke in 1874, he radicalized his position and defended the separation between church and state with Quintino Bocaiuva, founding member of the Republican Party, and members of the Presbyterian Church of Rio de Janeiro ${ }^{95}$.

\section{A Província}

Although elected deputy for the1867-1870 period, Tavares Bastos did not complete the mandate. In 1867, he opposed the Zacarias Cabinet, ceasing to be a deputy upon the dissolution of the House on July 18, 1868, amid the crisis of this cabinet. In the same year he published a circular in which he declared the definitive abandonment of participating in elections. Although he no longer held public office, the following years were of intense activities. His last years were of departure from public office, but not from political debate. In 1869 he began to direct with Lafayette Rodrigues Pereira the newspaper Diário do Povo. In the same year he began to collaborate with the newspaper A Reforma of the newly founded Clube da Reforma.

In 1870 A Provincia came to the public. This is the most complete work of Tavares Bastos, the one who best exposes his political thinking. It could also be said that in this text we find the Tavares Bastos of more mature ideas, although this notion should be treated with care: the reading of his complete work shows that his thinking has undergone

\footnotetext{
92 VIEIRA, David Gueiros. Op. Cit., p. 324.

93 Ibidem, p. 242.

94 Ibidem, p. 251.

95 Ibidem, p. 284-285.
} 
few changes since the publication of Os males do presente e as esperanças do futuro. In addition, the fundamental themes remain the same: the decentralization or federalization of Brazil, giving some autonomy to the provinces and ending imperialist unitarian centralism, which suffocated them and denied them practically any initiative. What happens in A Provincia is a much more complete and detailed exhibition. Other relevant information is that this work is a book, thought about and written as such, not a pamphlet or compilation of articles.

A Provincia is divided into three parts: the first, "Centralization and federation", with six chapters regarding the adoption of these two models in different parts of the world, including one specifically regarding the federation in the United States; the second, "Provincial institutions", with seven chapters regarding the concrete reality of Brazil at the time; finally, the third part, "Provincial interests", with eight chapters on how decentralization could affect different topics of government and administration in Brazil.

The references to the United States in A Provincia are very numerous and I will not mention each of them separately. But it is important to mention that at this time Tavares Bastos dedicates a whole chapter (the fifth) to write about the federation in the United States, although the references to the United States in the book are not restricted to this chapter (even before it, he mentions the USA as an example for Brazil numerous times). In fact, initially Tavares Bastos speaks mainly of England, and not of the USA. He also makes several references to Canada, Australia and New Zealand (something entirely new in Brazilian political discussions until then). The objective is to contrast the decentralization of the English colonial regime with the administrative centralization prevailing in the Brazilian monarchy. The point is mainly to demonstrate, through many examples, that the association between decentralization and anarchy, made by the Conservatives, is a myth. At the same time Tavares Bastos wants to demonstrate that decentralization is progress, using the examples of the USA, England and its colonies. Tavares Bastos also shows that, although decentralized, the US government is strong. According to his argument, the tools for progress are railroad and education, not centralization of ad- 
ministration. The examples of Canada, Australia, and New Zealand are especially significant: with them, Tavares Bastos breaks the central line of argumentation of the Conservatives: "decentralization is good for the US, but Brazil is not the US and is not prepared for this kind of government". What he wants to show is that, if younger countries like Canada, Australia and New Zealand are ready for decentralization (and benefit from it), why would not Brazil be?

\section{After A Província}

After A Provincia Tavares Bastos published two shorter and less comprehensive texts, A situação e o Partido Liberal, in 1872, and A reforma eleitoral e parlamentar, e constituição da magistratura: esboços e projetos de lei, in 1873. In $A$ situação e o Partido Liberal the references to the US are more punctual than in other texts, but they are also present. Once again, Tavares Bastos argues that "as in the case of the Anglo-American constitutions", we must repeal the centralizing laws in Brazil, "restoring the additional act, broadening the power of the assemblies, deferring them the proposal or the choice of the president, limited his authority to the provincial sphere, establishing, in short, the autonomy of the province". The autonomy of the provinces, according to the Anglo-Saxon model (especially the North American), would be the "essential condition for the success of the political reforms" ${ }^{\text {"96 }}$.

Although most of the themes (and the comparison with the US) were no longer a novelty in Tavares Bastos's writings, a new circumstance was present in 1872: the recovery of republicanism in Brazil and the emergence of the Republican Party. According to Tavares Bastos, "adhesions after adhesions, it is forming, at the expense of the Liberal and the Conservative too, the new Republican Party". The new party was favored, according to him, by the "quiescence of Liberals, no less than the noisy dissent of our adversaries". And above all, the Republican Party held up "an American flag": "the federation so friendly to

96 TAVARES BASTOS, Aureliano Cândido. Op. Cit., 1861. p. 153. 
the provinces" ${ }^{\prime 97}$. In other words, Tavares Bastos was concerned that the Republican Party was taking to itself a platform very dear to him, which he lamented that the Liberal Party was unable to put forth.

In A reforma eleitoral e parlamentar the references to the US as an example for Brazil are numerous again. Tavares Bastos calls the Brazilian government a "state council commission". In his view, the council of state served to "supply the insufficiency and inability of the ministers" who, ironically, are appointed freely by the emperor himself. This whole expedient was in his view manifestly contradictory and unnecessary, since "countries like England, Belgium and the United States" govern admirably well without their concurrence ${ }^{98}$. Tavares Bastos also states that "the population is the only practical basis for political representation". Consequently, "it is necessary to distribute proportionally to the provinces the chairs of the chamber". Periodic censuses could ensure proportional representation of the population, as in Belgium, Argentina and other countries, especially in the United States, where each province had "a legitimate influence proportional to the number of its inhabitants" $"$.

Tavares Bastos further states that "opponents are already beginning to feel the truth that we have always preached": the Senate must be temporary. Temporary and "elected by provincial assemblies, as in the United States". He mentions that "in a number of monarchical countries [Spain, Sweden, Belgium and Denmark], and all English colonies that have adopted representative institutions where, incidentally, there are ancient aristocracies, has already left the Senate to be lifelong". By mentioning other examples than the United Sates (specifically monarchies), he avoids the criticism that the United States were not a suitable comparison for Brazil. But there is no denying that his greatest example is the US, "whose constitution limited the senators' term to six years". In fact, also the "term preferred by our chamber of 1831 ".

\footnotetext{
97 Ibidem, p. 164.

98 Ibidem, p. 215.

99 Ibidem, p. 217.
} 
More than enough time, according to him, "because, as Stuart Mill ponders, the popular mandate should not exceed a five-year period" 100 .

Still looking at the US, it is possible to identify one last characteristic in Tavares Bastos" liberalism: similarly to the "immortal authors of the wisest political constitution, that of the United States" he was a champion of "checks and balances" both between the powers and between the powers and the population. His goal was to avoid both mob rule and despotism. This would be the role of the Senate "the most respectable of its institutions" in the United Sates ${ }^{101}$.

\section{Key political ideas}

Tavares Bastos left for the second time to Europe in 1874, with his wife and daughter. Once again he had health problems. His career was interrupted by his early death in Nice, France, on December 3, 1875.

As Joaquim Nabuco wrote, "Tavares Bastos was, by the American influence, predominant in his spirit, a natural Republican" ${ }^{102}$. That is to say: the admiration for the USA made Tavares Bastos approach Republican ideas, although he formally defended the monarchy. But the main thing is that before republicanism, came the admiration for the United States. No other thinker of Brazilian politics in the 19th century had a greater admiration for the United States and so strongly advocated Brazil's rapprochement with them. Nabuco is not the only one to emphasize Tavares Bastos in this way. Quintino Bocaiuva and the brothers Salvador and Lucio de Mendonça, members of the Republican Party, mentioned Tavares Bastos as a precursor of their republicanism and admiration for the $\mathrm{US}^{103}$.

\footnotetext{
${ }^{100}$ Ibidem, p. 223.

${ }^{101}$ Ibidem, p. 224.

${ }^{102}$ NABUCO, Joaquim. Um estadista do Império: Nabuco de Araujo: sua vida, suas opiniões, sua época, por seu filho Joaquim Nabuco. Rio de Janeiro: H. Garnier, 1897. livro 3, p. 105-106.

103 TAVARES BASTOS, Aureliano Cândido. Os males do presente e as esperanças do futuro, $2^{\mathrm{a}}$ ed. São Paulo: Companhia Editora Nacional, 1976 [1861]. p. 15-16.
} 
Tavares Bastos' admiration for the United States may have been influenced, in addition to his father, by professor José Tell Ferrão ${ }^{104}$, whom Tavares Bastos thanks in a note in Cartas do Solitário ${ }^{105}$. The place of the United States in Tavares Bastos' political thinking can be summarized as follows: the United States is an example for Brazil. And contrary to the opinion of other Brazilians (especially members of the Conservative Party), they are an example for which Brazil is prepared, even if differences between the two imply adaptations in the copy.

Ivo Coser also observed this nuance in Tavares Bastos' thought: while the United States is a decisive example for Brazil, the transposition of the example to the Brazilian reality cannot be accomplished without considering the peculiarities of one reality and the other ${ }^{106}$. According to him, in the 1860s and 1870s Tavares Bastos sought to reverse the centralization initiated with the Conservative Regress of 1837. Another way of saying the same thing is that Tavares Bastos defended the Additional Act of 1834 as a feasible political program. The set of ideas advocated by Tavares Bastos is that decentralization (or federation) would not lead the country to the anarchy of Hispanic America, but something closer to the United States. In a classic liberal thought, decentralization would liberate society's interest from the bonds imposed by the centralizing state, leading to the development of society.

Still in the reading of Ivo Coser, Tavares Bastos adopted a critical stance toward the reformers who took power in 1831. Although the reforms implemented at that time (notably the Code of Process) had the correct principles (decentralizing power, making it responsible before citizens and their interests), the reformers who adopted the US federalist model in Brazil lacked the perception of differences between

${ }^{104}$ MORAIS FILHO, Evaristo de. Op. Cit., p. 12.

105 TAVARES BASTOS, Aureliano Cândido. Cartas do Solitário, 4ª ed. São Paulo: Companhia Editora Nacional, 1975 [1862]. p. 415, nota 70.

${ }^{106}$ COSER, Ivo. O pensamento do visconde de Uruguai e o debate entre centralização e federalismo. Belo Horizonte: Ed. UFMG, 2008. p. 155-156. 
the two countries. According to Tavares Bastos, making the main magistrate posts elected or chosen by the municipality resulted in "partial revolts and a general disorder".

Ivo Coser interprets that the "democratic form" proposed by Tavares Bastos is directly associated to the North American model. Following the description of Alexis de Tocqueville, Tavares Bastos believed that in the United States the state is formed from the bottom up: the commune comes before the county, the county before the state, and the state comes before the Union. Tavares Bastos shares this federalist thinking. However, for him to apply it in Brazil through a specific measure (as was the case of the Code of Process of 1831) would result in "general disorder". The episode of 1831 meant for Tavares Bastos not the abandonment of the federalist form, but a nuance in its application: from him decentralization was not a principle of isolated democratic organization, but rather something that must be understood as an instrument from which interest shapes the state. According to Ivo Coser, "if this interest is threatened by the democratic form assumed by the decentralization reforms, they must be contained"107.

\section{Conclusion}

I believe it is clear enough from all these examples that Tavares Bastos believed that the United States was a central example for Brazil, and an example for which Brazil was ready, contradicting some Conservatives who, although expressing admiration for the United States, did not consider Brazil able to follow such an example. Although Tavares Bastos recognized that the particularities of each country would demand adaptations when bringing the American example to Brazil, the general picture is simple: Brazil must undergo a series of reforms inspired by the US political and administrative model, the most central being decentralization or federalization.

107 TAVARES BASTOS, Aureliano Cândido. A Província: Estudo sobre a descentralização no Brasil. Edição fac-similar. Brasília: Senado Federal, 1997 [1870]. p. 108-109. 
Similarly, Tavares Bastos vehemently defended the diplomatic rapprochement between the two countries. Brazil should build stronger ties with the US, especially trade ties, following the liberal principle that trade is a positive sum game. But also, and again obeying a liberal principle, trade would strengthen ties between the two countries in other areas, reinforcing the US presence as an example for Brazil.

\section{Bibliographic references}

BRANDÃO, Gildo Marçal. Linhagens do pensamento político brasileiro. São Paulo: Aderaldo \& Rothschild Editores, 2007.

BURNS, E. Bradford. A aliança não escrita: o barão do Rio Branco e as relações Brasil-EUA. Brasília: Funag, 2003.

CARVALHO, José Murilo de. A construção da ordem. Brasília: Editora da UnB, 1980.

. Dom Pedro II. São Paulo: Companhia das Letras, 2007.

CARVALHO, José Murilo de (org.). Entre a autoridade e a liberdade [ntrodução]. Paulino Fosé Soares do Souza, visconde do Uruguai. São Paulo: Editora 34, 2002.

Federalismo y centralización en el Imperio brasileño: historia y argumento. In: CARMAGNANI, Marcelo (org.). Federalismos latino-americanos. Mexico/ Brasil/ Argentina. México: Fondo de Cultura Económica, 1993.

COSER, Ivo. O debate entre centralizadores e federalistas no século XIX: a trama dos conceitos. Rev. bras. Ci. Soc., São Paulo, vol. 26, n. 76, p. 191206, junho 2011.

- O pensamento do visconde de Uruguai e o debate entre centralização e federalismo. Belo Horizonte: Ed. UFMG, 2008.

Diário de 1862. Introdução e notas de Hélio Viana, Separata do Anuário do Museu Imperial, vol. 17, Petrópolis, 1956.

FERREIRA, Gabriela Nunes. Centralização e descentralização no Império: o debate entre Tavares Bastos e visconde do Uruguai. São Paulo: Departamento de Ciência Política da Universidade de São Paulo/Editora 34, 1999.

GAYLE, Thornbrough; RIKER, Dorothy; CORPUZ, Paula (ed.). The diary of Calvin Fletcher, 1848-1852, including letters to and from Calvin Fletch- 
er. Indianapolis: Indiana Historical Society, 1975. vol. IV.

. The diary of Calvin Fletcher, 1853-1856, including letters to and from Calvin Fletcher. Indianapolis: Indiana Historical Society, 1977. vol. V. The diary of Calvin Fletcher, 1857-1860, including letters to andfrom Calvin Fletcher. Indianapolis: Indiana Historical Society, 1978. vol. VI. HILL, Lawrence F. Diplomatic relations between Brazil and the United States. Durham: Duke University Press, 1932.

MATTOS, Ilmar Rohloff de. O Tempo Saquarema, $5^{\text {a }}$ ed. São Paulo: Editora Hucitec, 2004.

MORAIS FILHO, Evaristo de. As ideias fundamentais de Tavares Bastos. Rio de Janeiro: Difel, 1978.

NABUCO, Joaquim. Um estadista do Império: Nabuco de Araujo: sua vida, suas opiniões, sua época, por seu filho Joaquim Nabuco. Rio de Janeiro: H. Garnier, 1897.

PARANHOS, José Maria da Silva [Alvaro da Costa Franco, org.]. Com a palavra, o visconde do Rio Branco: a política exterior no Parlamento imperial. Rio de Janeiro: CHDD; Brasília: Funag, 2005.

REGO, Walquiria. Um liberalismo tardio: Tavares Bastos, reforma e federação. Tese (Doutorado em Ciência Política), Departamento de Ciência Política, Universidade de São Paulo (mimeo), São Paulo, 1989.

ROSI, Bruno Gonçalves. Brazil-USA relations from Tiradentes to baron of Rio Branco. Brazilian fournal of International Relations, Marília, vol. 6, n. 1, p. 37-60, jan/abr. 2017.

SANTOS, Wanderley Guilherme dos. Ordem burguesa e liberalismo politico. São Paulo: Duas Cidades, 1978.

TAVARES BASTOS, Aureliano Cândido. A Província: Estudo sobre a descentralização no Brasil. Edição fac-similar. Brasília: Senado Federal, 1997 [1870]. 1937 [1866].

O vale do Amazonas. São Paulo: Companhia Editora Nacional, . Cartas do Solitário, $4^{a}$ ed. São Paulo: Companhia Editora Nacional 1975 [1862].

. Os males do presente e as esperanças do futuro, $2^{\mathrm{a}}$ ed. São Paulo: Companhia Editora Nacional, 1976 [1861]. 
VAINFAS, Ronaldo (org.). Dicionário do Brasil Imperial. Rio de Janeiro: Objetiva, 2008.

VIANNA, Luis Werneck. A revolução passiva: iberismo e americanismo no Brasil. Rio de Janeiro: Revan, 1997.

- Americanistas e iberistas: a polêmica de Oliveira Viana com Tavares Bastos. Dados Revista de Ciências Sociais, Rio de Janeiro, vol. 34, n. 3, 1991, p. 145-189.

VIEIRA, David Gueiros. O protestantismo, a maçonaria e a questão religiosa no Brasil. Brasília: Editora Universidade de Brasília, 1980.

Recebido em: 07/02/2017 - Aprovado em: 08/02/2018 